\title{
KEBIJAKAN EKONOMI DAN PENINGKATAN DAYA SAING INDONESIA MENGHADAPI MASYARAKAT EKONOMI ASEAN 2015
}

\author{
Suharyono \\ Sekolah Pascasarjana, Program Studi Manajemen, Universitas Nasional \\ Suharyono_unas@yahoo.co.id
}

\begin{abstract}
ABSTRAK
Sejak dibentuknya Masyarakat Ekonomi ASEAN dalam Kesepakatan II di Bali tahun 2003, Indonesia terus melakukan daya-upaya memperkuat daya saing ekonominya, terutama melalui instrument kebijakan ekonomi oleh negara guna menciptakan situasi kondusif bagi perkembangan sektor usaha. Makalah ini akan membahas tantangan-tantangan yang dihadapi Indonesiayang mencakup neraca perdagangan, daya saing para usahawan, dan taraf produktivitas warganegara. Bagaimana pemerintah saat ini mampu menyediakan paket-paket kebijakan ekonomi yang tepat? Temuan dari pembahasan tentang hal ini adalah bahwa kebijakan-kebijakan ekonomi pemerintahan Joko Widodo yang mutakhir belum berhasil mencapai hasil yang baik guna menangani tantangan-tantangan di atas .
\end{abstract}

Kata kunci : Kebijakan ekonomi, Negara, Persaingan, Masyarakat Ekonomi ASEAN

\section{ABSTRACT}

Since 2003 Bali Concord II that sett up (ASEAN Economic Community/AEC, Indonesia has been engaged in the efforts of strengthening the country especially setting forth economic policy that is condusive to achieving the country's level of competition. The paper shall deal with challenges that Indonesia has faced in the issue. The challenges that are identified include balance of trade, dependable entrepreneurs, and rate of productivity of manpower.How has the government come up with sound economic policies? The account finds that the most recent economic policies of Joko Widodo have not achieved better results in coping the cahallenges.

Keywords : Economic policy, State, Competition, ASEAN Economic Community. 


\section{PENDAHULUAN}

Globalisasi mendorong meningkatnya hubungan ketergantungan antar bangsa dan antar negara di seluruh dunia. Hubungan ketergantungan ini meliputi berbagai bidang, baik bidang pertahanan dan keamanan, ekonomi, politik maupun sosial budaya. Hubungan ketergantungan ini semakin dibutuhkan antara satu negara dengan negara lain untuk menciptakan masa depan dunia sebagaimana yang diimpikan bersama; yaitu dunia dengan tatanan kehidupan yang baru, yang aman, sentosa dan sejahtera. Stiglitz (2003) menjelaskan bahwa globalisasi telah mengurangi perasaan terisolasi yang dirasakan di banyak negara-negara berkembang dan telah memberikan akses kepada masyarakat negara berkembang akan pengetahuan yang mungkin di luar jangkauan orang-orang paling kaya sekalipun di semua negara pada satu abad yang lalu.

Dalam menanggapi masalah globalisasi terdapat banyak pendapat, namun kita dapat menjelaskan bahwa globalisasi merupakan proses alamiah dalam aspek sosial dan budaya seluruh bangsa dan negara di dunia semakin terikat satu sama lain untuk mewujudkan tatanan kehidupan baru yang membiaskan batas-batas geografis, ekonomi dan budaya masyarakat di antara negara-negara di dunia. Pada prinsipnya, perkembangan ekonomi dunia telah mendorong negara-negara ASEAN untuk membentuk kerjasama ekonomi. Hal ini dimulai dengan disyahkannya deklarasi Bangkok tahun 1967 yang bertujuan untuk mempercepat pertumbuhan ekonomi, kemajuan sosial dan pengembangan budaya. Pada akhirnya, dalam menghadapi perkembangan ekonomi global, kerjasama ekonomi ASEAN diarahkan untuk membentuk komunitas ekonomi ASEAN (ASEAN Economic Community/AEC). Kemudian ternyata $A E C$ yang mulai dicanangkan pada tahun 2015 dapat berjalan relatif lebih cepat dibandingkan kerjasama di bidang keamanan, politik dan sosial budaya (Bustami, 2015).

Pada saat ini, Indonesia harus mempersiapkan diri dan berpacu dengan waktu dalam menghadapi Pasar Bebas Asia Tenggara / AFTA yang merupakan Masyarakat Ekonomi ASEAN (MEA) yang sudah bergulir sejak tahun 2015. Beberapa sektor barang industri menjadi basis dalam perdagangan MEA. Barang-barang tersebut antara lain golongan produk pertanian, elektronik, perikanan, karet, tekstil, otomotif dan produk berbasis kayu. Di samping produk industri terdapat lima sektor jasa dalam wilayah perdagangan MEA, yaitu transportasi udara, e-asean, pelayanan kesehatan, pariwisata dan jasa logistik.

Keingingan negara-negara di Asia Tenggara untuk membentuk MEA didorong oleh perkembangan kebutuhan di antara anggota negara Asia Tenggara. Di sisi lain perkembangan ekonomi dunia yang maju dengan pesat akibat perkembangan teknologi, khususnya teknologi komunikasi dan sistem 
informasi menyebabkan batas-batas suatu negara menjadi bias dan kebutuhan untuk membentuk komunitas semakin mendesak.

\section{INDONESIA DAN PERMASALAHANNYA}

Indonesia menjadi tempat dilaksanakannya KTT ASEAN ke-9 pada tahun 2003 di Bali yang menghasilkan Bali Concord II yang menyepakati pembentukan ASEAN Community. Komunitas ini dibentuk guna mempererat integrasi di antara anggota negara ASEAN melalui tiga komunitas yang disesuaikan dengan visi ASEAN 2020, yaitu komunitas pada bidang keamanan politik (ASEAN Pilitical-Security Community), dalam bidang ekonomi (ASEAN Economic Community / AEC) dan dalam bidang sosial budaya (ASEAN Socio-Culture Community).

Wangke (2015) menjelaskan bahwa untuk membantu integrasi ekonomi ASEAN dibuat blueprint AEC yang memuat empat pilar utama, yaitu (1) ASEAN sebagai pasar tunggal dan berbasis produksi tunggal akan didukung oleh elemen aliran bebas, barang, jasa, investasi, tenaga kerja terdidik dan aliran modal yang lebih bebas; (2) ASEAN sebagai kawasan dengan daya saing ekonomi tinggi, dengan elemen peraturan kompetisi, perlindungan konsumen, hak atas kekayaan intelektual, pengembangan infrasruktur, perpajakan dan e-commerce; (3) ASEAN dengan kawasan ekonomi yang merata dengan elemen pengembangan usaha kecil dan menengah / UKM, dan prakarsa integrasi ASEAN untuk negara-negara Kamboja, Myanmar, Laos dan Vietnam; dan (4) ASEAN sebagai kawasan yang terintegrasi dengan perekonomian global memiliki elemen pendekatan yang koheren dalam hubungan ekonomi di luar kawasan ASEAN dan meningkatkan peran serta jejaring produksi global.

Posisi Indonesia dalam komunitas ekonomi ASEAN berperan penting, bahkan sangat menentukan. Kekuatan ekonomi ASEAN yang didukung India, Tiongkok dan negara-negara ASEAN memiliki kekuatan ekonomi dengan nilai GDP sebesar 3,36 triliun USD dan laju pertumbuhan 5,60\%, serta memiliki jumlah penduduk 617,68 juta orang. Dalam hal ini, Indonesia merupakan negara terbesar di ASEAN, dengan luas wilayah mencakup 43\% dari seluruh wilayah ASEAN, jumlah penduduk Indonesia mencapai 40\% dari jumlah penduduk ASEAN dan memiliki porsi GDP 38\% dari total GDP ASEAN (Kuntadi, 2015).

Di sisi lain, kondisi Indonesia dalam era perdagangan bebas ASEAN (AFTA) harus dilindungi melalui regulasi perdagangan. Dalam hal ini terdapat regulasi perdagangan yang cukup penting yaitu UU No. 7 Tahun 2014 tentang "Strategi perdagangan sebagai salah satu strategi Indonesia untuk membendung membanjirnya produk impor yang masuk ke Indonesia". UU No. 7 Tahun 2014 mengatur ketentuan umum tentang perijinan bagi pelaku usaha yang terlibat dalam kegiatan perdagangan, agar menggunakan 
bahasa Indonesia di dalam pelabelan dan penggunaan produk dalam negeri. Dengan berlakunya UU No. 7 Tahun 2014 tersebut, pemerintah berkewajiban untuk mengendalikan ketersediaan bahan kebutuhan pokok di seluruh wilayah Indonesia. Selain itu pemerintah juga berkewajiban menentukan larangan atau pembatasan barang dan jasa untuk kepentingan nasional.

Regulasi di bidang perdagangan sebagaimana tertuang dalam UU RI No. 7 Tahun 2014 tersebut di latar belakangi oleh posisi ekspor Indonesia ke pasar ASEAN yang pada akhir tahun 2014 baru mencapai sekitar 23\% dari nilai ekspor Indonesia keseluruhan. Tujuan ekspor Indonesia sampai saat ini ternyata masih difokuskan pada pasar tradisional, antara lain Amerika, Tiongkok dan Jepang. Dalam aspek kemampuan bersaing yang diukur dengan global competitivenes index, Indonesia masih berada posisi yang memprihatikan. Dari 148 negara, Indonesia berada pada urutan ke-38, hanya lebih baik dari posisi Filipina dan Vietnam. Berdasarkan global competitivenes index, Singapura menempati posisi ke-2, Malaysia di posisi ke-24, Thailand di posisi ke-37, sedangkan Indonesia di posisi urutan ke-38, sementara itu Philipina dan Vietnam, masing-masing di posisi 59 dan 70.

Akibat ketatnya persaingan di pasar ASEAN, menyebabkan transaksi perdagangan Indonesia mengalami defisit dagang dengan Thailand hingga mencapi 1,048 miliar USD padahal global competivenes index Indonesia hanya berselisih satu point dengan Thailand. Namun demikian, secara menyeluruh neraca pedagangan Indonesia pada bulan Februari 2014 masih surplus sebesar 843,4 juta USD dan turun menjadi 673,2 juta USD pada bulan Maret 2014, serta pada Jan-Sep 2015 mencapai surplus perdagangan sebesar 7,13 Miliar USD atau rata-rata 781,11 juta USD per bulan.

Surplus perdagangan Indonesia tersebut ternyata belum mencerminkan kekuatan struktur ekspor Indonesia. Industri atas produkproduk yang diekspor oleh Indonesia (selain produk pertanian), sebagian besar masih bergantung dengan bahan baku impor. Kondisi ini sangat rentan karena ekspor Indonesia akan bergantung dengan ketersediaan bahan baku dunia yang harganya akan menjadi mahal jika terjadi pelemahan kurs rupiah khususnya terhadap USD. Di sisi lain, Indonesia memiliki jumlah penduduk terbesar di ASEAN, namun kenyataannya hanya mempunyai 450.000 wirausaha atau $0,18 \%$ dari total penduduk Indonesia padahal jumlah wirausaha yang ditargetkan pada tahun 2015 hanya $2 \%$ dari total penduduk Indonesia (Nazara, 2014).

Dibandingkan Amerika yang memiliki wirausaha sebanyak 12\% dari total penduduk Amerika dan Singapore 7,20\%, serta Malaysia 3\%, sungguh jumlah wirausaha Indonesia jauh dari ideal untuk mendorong daya saing Indonesia dalam kancah ekonomi dunia, bahkan di ASEAN sekalipun. Belum lagi jika kita bicara tentang kualitas wirausaha Indonesia yang berkorelasi positif dengan tingkat pendidikan. Hasil Sakernas (2007) memperlihatkan 
bahwa dari lulusan perguruan tinggi, hanya $26,29 \%$ yang menjadi wirausaha, sedangkan lulusan SLTA dan di bawahnya mencapai 73,71\%. Inilah data yang mengindikasikan bahwa di Indonesia, semakin tinggi pendidikannya semakin rendah jiwa kewirausahaannya. Walaupun ada beberapa kasus yang unik dimana beberapa wirausahawan terkaya di dunia bukanlah berasal dari mereka yang berkemampuan akademik optimal, misalnya Wareen Buffet (pemilik pialang saham terkemuka) dan Bill Gate (pemilik Microsoft).

Kajian dari aspek jumlah penduduk, menunjukkan bahwa jumlah penduduk yang besar jika tidak dikelola secara baik tidak akan memberikan nilai tambah yang berarti dalam perekonomian. Penduduk yang berprofesi sebagai pekerja, jika tidak memiliki tingkat produktivitas yang memadai akan menjadi kendala dalam menghadapi pasar yang bersaing secara ketat. Produktivitas tenaga kerja Indonesia berdasarkan proporsi terhadap Product Domestic Bruto $(P D B)$ per tenaga kerja, jauh lebih rendah dibandingkan Singapore, Malaysia, Thailand dan ASEAN. Dalam hal ini, produktivitas tenaga kerja Indonesia dengan ukuran PDB adalah 9,50\%, jauh di bawah Singapore yang mencapai $92,00 \%$, Malaysia 33,30\%, Thailand $15,40 \%$ dan ASEAN 10,70\%. Dalam hal produktivitas dengan ukuran PDB, Indonesia hanya sedikit lebih unggul dibandingkan Philipinnes $(9,20 \%)$ dan unggul secara meyakinkan terhadap Vietnam $(5,50 \%)$, Laos (5,00\%), Cambodja (3,60\%) dan Myanmar (3,40\%).

Dari sisi liberalisasi perdagangan, produk Indonesia praktis tidak mengalami hambatan. Bahkan sektor usaha yang berbasis pada ekonomi kerakyatan (UMKM) berpeluang untuk menembus pasar ASEAN. Pemerataan pembangunan sebagai bagian dari penguatan ekonomi kerakyatan memang telah dilakukan oleh pemerintah. Mulai tahun 2011 pemerintah Indonesia telah mengarahkan investasi Indonesia ke wilayahwilayah di luar pulau jawa dengan memberikan tax holiday. Melalui upaya ini diharapkan pertumbuhan ekonomi tidak lagi terpusat di pulau Jawa, melainkan menyebar di luar wilayah pulau Jawa.

Usaha lain yang dilakukan oleh pemerintah adalah membentuk kluster untuk melakukan pembinaan UMKM agar daya saingnya meningkat. Sektorsektor yang akan menjadi sektor unggulan Indonesia dalam pasar MEA 2015 harus pula ditempatkan secara benar sehingga memiliki tingkat kompetensi yang memadai, antara lain sektor Sumber Daya Alam, Informasi Teknologi dan Ekonomi Kreatif (Khususnya UMKM). Kesepakatan MEA juga mendorong masuknya tenaga kerja asing ke Indonesia. Kondisi ini semakin memojokkan posisi ketenagakerjaan Indonesia, kecuali jika pemerintah memberikan persyaratan yang memadai bagi tenaga kerja asing yang masuk Indonesia (misalnya harus bisa berbahasa Indonesia yang baik dan benar).

Menurut Saparini (2015), posisi Indonesia dalam menghadapi MEA 2015 yang perlu mendapatkan perhatian khusus antara lain adalah (1) 
Indonesia berpotensi sekedar sebagai pemasok energi dan bahan baku bagi industrialisasi di kawasan ASEAN, sehingga manfaat yang diperoleh dari kekayaan sumber daya alam akan minimal, sementara itu defisit neraca perdagangan barang Indonesia yang saat ini paling besar di antara negaranegara ASEAN akan semakin bertambah; (2) melebarkan defisit neraca perdagangan jasa seiring peningkatan perdagangan barang; (3) membebaskan aliran tenaga kerja sehingga Indonesia harus mengantisipasi dengan menyiapkan strategi karena potensi membanjirnya tenaga kerja asing; dan (4) masuknya investasi ke Indonesia dari dalam dan luar ASEAN.

Permasalahan dunia usaha di Indonesia dikemukakan oleh Simanjuntak dalam seminar Segmen Integrasi Ecosoc di Jakarta pada Februari 2015. Pemrasaran ini merilis hasil survei terhadap faktor-faktor yang menjadi permasalahan utama dalam menjalankan bisnis di Indonesia, yaitu :

Korupsi

Birokrasi pemerintahan yang tidak efisien

Ketidakseimbangan penyediaan infrastruktur

Ketidakstabilan kebijakan

Akses keuangan

Kurangnya tenaga kerja terdidik

Etika kerja yang buruk pada ketenagakerjaan nasional

Pemerintahan yang tidak stabil

Inflasi

Peraturan perpajakan

Tarif pajak

Regulasi pembatasan tenaga kerja

Kriminalitas dan pencurian

Buruknya kesehatan masyarakat

Regulasi nilai tukar valuta asing
$15,40 \%$

$14,30 \%$

$9,50 \%$

$7,40 \%$

$7,20 \%$

$6,40 \%$

$6,20 \%$

$6,10 \%$

$6,10 \%$

$6,00 \%$

$4,20 \%$

$3,60 \%$

$2,80 \%$

$2,50 \%$

$2,30 \%$

\section{KEBIJAKAN EKONOMI DAN PENGUKURAN DAYA SAING}

Untuk mempertahankan pertumbuhan ekonomi di antara tekanan perekonomian global dalam menghadapi MEA 2015, stimulus fiskal sebagai pendukung pertumbuhan jangka pendek sangat dibutuhkan. Peningkatan daya saing Indonesia diharapkan dapat ditingkatkan dengan di luncurkannya beberapa kebijakan ekonomi pemerintahan Jokowi yang dimulai pada September 2015.

Kebijakan ekonomi 9 September 2015 di gulirkan pemerintah untuk empat aspek sasaran, yaitu (1) akselerasi penyerapan anggaran dengan mendorong program-program prioritas pemerintah dan mendorong pertumbuhan ekonomi; (2) peningkatan daya beli dengan mendorong tingkat pertumbuhan konsumsi rumah tangga dan menjaga stabilitas harga; (3) 
insentif dunia usaha dengan memberikan stimulus pertumbuhan sektor prioritas melalui pertumbuhan investasi, penguatan daya saing produk dalam negeri dan insentif penunjang lainnya; (4) memperkuat daya saing dengan memperkuat daya saing potensi lainnya dan menstimulus perkembangan potensi baru.

Kebijakan ekonomi 29 September 2015 digulirkan pemerintah dengan 4 (empat) aspek sasaran, yaitu (1) persetujuan tax allowance dan tax holiday dengan cara mempercepat layanan investasi dalam bentuk memangkas perizinan investasi di kawasan industri; (2) Insentif PPN Impor barangbarang tertentu dengan memberikan kelonggaran PPN tidak dipungut untuk beberapa industri alat transportasi (utamanya untuk galangan kapal, kereta api, pesawat dan suku cadangnya); (3) pembentukan pusat logistik berikat yaitu Cikarang, terkait manufactur dan Merak, Banten, terkait Bahan Bakar Minyak (BBM); (4) insentif pajak deposito dengan menurunkan pajak deposito bagi eksportir yang melaporkan Devisa hasil Ekspor (DHE) kepada Bank Indonesia (BI).

Kebijakan ekonomi 7 Oktober 2015 digulirkan pemerintah dengan 3 (tiga) aspek sasaran, yaitu (1) penyesuaian harga BBM dengan menurunkan harga BBM, listrik dan gas untuk industri; (2) perluasasn penerima KUR dengan memperbesar kriteria penerima KUR, dan (3) penyerdahaan izin pertanahan dengan melakukan smplifikasi persetujuan investasi.

Kebijakan ekonomi 15 Oktober 2015 yang digulirkan pemerintah dengan 3 (tiga) aspek sasaran, yaitu (1) peningkatan kesejahteraan pekerja dengan pemberian jaring pengaman melalui kebijakan upah minimum dengan sistem formula untuk memastikan pekerja / buruh tidak jatuh ke dalam upah murah; (2) kebijakan KUR yang lebih murah dan meluas dengan menurunkan tingkat bunga dari $22 \%$ menjadi $12 \%$; dan (3) mendorong ekspor untuk mencegah PHK dengan cara memberikan dukungan kepada usaha kecil menengah yang berorientasi ekspor maupun terlibat pada kegiatan yang mendukung ekspor melalui lembaga pembiayaan ekspor Indonesia.

Pengukuran daya saing di dasarkan pada 3 (tiga) kelompok pilar yang terdiri atas 12 pilar, yaitu : Pertama, pilar yang menjadi kunci faktor pendorong ekonomi, yaitu kelompok pilar dasar yang terdiri atas (a) kondisi makro ekonomi, (b) infrastruktur, (c) kesehatan, dan (d) pendidikan. Kedua, kelompok pilar efisiensi yang terdiri atas (a) pendidikan dan pelatihan (b) efisiensi pasar barang, (c) efisiensi pasar tenaga kerja, (d) pengembangan pasar uang, (e) kesiapan teknologi dan (f) ukuran pasar; Ketiga, kelompok pilar inovasi, yang terdiri atas (a) ketersediaan teknologi dan (b) kemudahan berusaha. 


\section{MENGAPA KEBIJAKAN PEMERINTAH MENGALAMI KEGAGALAN}

Pemerintah yang terpilih untuk mengemban amanat rakyat haruslah pemerintah yang diisi oleh orang-orang yang berjiwa pemimpin dan bukan penguasa. Pemerintah yang berjiwa pemimpin selalu melihat keluar (outwork looking) yaitu untuk kepentingan rakyat. Sementara pemerintah yang berjiwa penguasa akan selalu melihat kedalam (in-work looking) yaitu melihat kepentingan kelompoknya dan kepentingan dari golongan yang dibutuhkan untuk melanggengkan kekuasaannya.

Kebijakan pemerintah dari seorang yang berjiwa pemimpin, jika diterapkan adalah dalam rangka melakukan stabilisasi dan pertumbuhan ekonomi nasional, serta mempunyai tujuan akhir untuk kesejahteraan rakyat. Peran pemerintah di dalam pergerakan ekonomi nasional dibutuhkan karena adanya beberapa alasan, antara lain (1) untuk memenuhi perintah konstitusi negara, (2) mengatur persaingan usaha, (3) mengatur barang-barang publik, (4) mengatur masalah eksternalitas, (5) mengatasi ketimpangan ekonomi dan informasi pasar, serta (6) mengatasi pengangguran, inflasi dan ketidak merataan dalam pembangunan ekonomi.

Permasalahan yang dihadapi dalam kaitannya dengan menghadapi ekonomi global dan MEA adalah kemungkinan adanya kegagalan dari kebijakan pemerintah walaupun bertujuan untuk meningkatkan daya saing negara. Beberapa alasan yang dapat dikemukakan mengapa kebijakan pemerintah gagal dan tidak sesuai dengan apa yang diharapkan, antara lain adalah (1) tidak mendapat dukungan dari seluruh stakeholder, (2) kebijakan utama tidak disertai dengan kebijakan pendukung yang komprehensif dan dilakukan bersamaan dengan kebijakan utama, (3) kebijakan yang benar namun dilakukan pada waktu yang salah, (4) kebijakan yang salah dilakukan pada waktu yang salah, dan (5) masyarakat telah kehilangan kepercayaan kepada pemerintah (public distrust).

Di Indonesia sendiri sudah dijelaskan secara tegas dalam UUD 1945 khususnya pasal 33, mengenai peran negara dalam perekonomian dan bangun ekonomi kerakyatan. Makna pasal 33 UUD 1945 sebagaimana dimaksudkan pada ayat 1 adalah bahwa perekonomian disusun sebagai suatu usaha bersama berdasar azas kekeluargaan; ayat 2 menyatakan bahwa cabangcabang produksi yang penting bagi negara dan menguasai hajat hidup orang banyak dikuasai oleh negara; ayat 3 menyatakan bahwa bumi, air dan segala kekayaan yang terkandung di dalamnya dikuasai oleh negara dan dipergunakan bagi sebesar-besarnya kemakmuran rakyat.

Sementara itu bangun ekonomi kerakyatan dipertegas pada pasal 27 ayat 2 dan pasal 34 UUD 1945 yang memastikan diterapkannya ekonomi kerakyatan di Indonesia dengan ciri-ciri (1) mengembangkan koperasi dan BUMN, (2) memastikan pemanfaatan kekayaan nasional untuk kemakmuran 
rakyat, (3) menjaga stabilitas moneter, (4) menjaga hak setiap warganegara Indonesia untuk mendapatkan pekerjaan dan penghidupan yang layak, serta (5) memelihara fakir miskin dan anak terlantar.

Praktek ekonomi Indonesia yang mengganggu kesetiakawanan nasional dan menurunkan gairah masyarakat untuk berperan serta dalam pembangunan adalah adanya indikasi kuat bahwa praktek ekonomi Indonesia adalah "Neoliberal" yang terselubung dalam ekonomi Kerakyatan. Hal ini dapat diindikasikan dari ciri-ciri praktek ekonomi Indonesia yang berlaku hingga saat ini, antara lain (1) selalu mengandalkan mekanisme pasar sebagai pilar untuk menjaga stabilitas harga, (2) mengembangkan sektor swasta dan melakukan privatisasi BUMN sebagai prioritas utama, (3) memacu laju pertumbuhan ekonomi dengan investasi asing, (4) anggaran ketat dengan menghapuskan subsidi, (5) lebih memprioritaskan stabilitas pasar uang daripada pasar barang.

\section{STRATEGI PENINGKATAN DAYA SAING}

Strategi peningkatan daya saing harus diartikan sebagai upaya agar negara Indonesia dapat beradaptasi dengan perubahan lingkungan, baik lingkungan internal maupun lingkungan eksternal (lingkungan MEA dan Global). Ansoff (1990) dengan tegas menyatakan bahwa " organisasi yang sukses bukanlah organisasi yang besar, melainkan organisasi yang dapat beradaptasi dengan lingkungan. Jika lingkungan internal menunjukkan posisi kekuatan dan kelemahan, maka lingkungan eksternal akan menunjukkan adanya peluang dan tantangan (David, 2015).

Strategi peningkatan daya saing sebenarnya sudah didukung oleh aturan yang jelas yang mengatur perilaku usaha para pengusaha. Dalam hal ini, pelaku usaha di Indonesia dalam menjalankan kegiatan usahanya berasarkan demokrasi ekonomi dengan memperhatikan keseimbangan antara kepentingan pelaku usaha dan kepentingan umum. Di samping itu harus dilakukan peningkatan ekonomi nasional untuk meningkatkan kesejahteraan rakyat dan mewujudkan iklim usaha kondusif. Hal ini dilakukan dengan mengatur persaingan usaha yang sehat sehingga menjamin kepastian kesempatan berusaha yang sama bagi para pelaku usaha besar, pelaku usaha menengah dan pelaku usaha kecil ((Undang-Undang Nomer 5 Tahun 1999 Tentang Larangan Praktek Monopoli, Pasal 2-3).

Grant (1995) menjelaskan adanya empat penentu sukses dalam melaksanakan suatu strategi, yaitu (1) sasaran yang jelas, (2) pemahaman yang jelas dan akurat tentang lingkungan eksternal, (3) pemahaman yang jelas dan akurat tentang kekuatan dan kelemahan organisasi, serta (4) implementasi yang efektif. Sementara itu proses pelaksanaan strategi dijelaskan oleh Wheelen dan Hunger (2006) bahwa strategi harus dimulai dari pemetaaan informasi lingkungan pembuat strategi, kemudian dilanjutkan 
dengan membuat formulasi strategi, melakukan implementasi dari strategi terpilih dan pada akhirnya melakukan evaluasi dan kontrol terhadap kinerja setelah strategi tersebut diimplementasikan. Sementara itu, Hrebiniak (2005) menjelaskan bahwa orang-orang yang sukses harus memiliki motivasi, kemampuan, komitmen dan mampu menciptakan, serta mengikuti rencanarencana dalam sebuah tindakan yang akan berpengaruh terhadap keberhasilan atas pelaksanaan dari kerja kerasnya.

Selankutnya, dengan memahami pendapat para ahli tersebut, maka praktek kebijakan di suatu negara tidak terlepas dari kemampuan para pembuat kebijakan terhadap apa yang harus diputuskan dengan memahami semua faktor yang masuk dalam pertimbangan ketika akan membuat kebijakan. Sementara itu implementasi dan segala konsekuensi dari dikeluarkannya kebijakan harus pula dipahami mulai saat merencanakan kebijakan dan tidak diputuskan secara parsial dan sporadis hanya ketika implementasi kebijakan tersebut mengalami masalah.

\section{STRATEGI PEMBANGUNAN YANG BERPIHAK PADA RAKYAT DAN KONSTITUSI}

Strategi pembangunan ekonomi yang dipilih oleh pemerintah Indonesia akan mendapat dukungan partisipasi penuh masyarakat dalam pelaksanaannya jika strategi tersebut mempertimbangkan secara utuh bangun ekonomi dan pembangunan ekonomi dengan mengacu UUD 1945 pasal 33 dan pasal 27 ayat 2 serta pasal 34. Walaupun berselubung pada sistem ekonomi kerakyatan, namun dalam kenyatannya indikasi praktek ekonomi "Neoliberal" jelas terlihat terlihat dari aspek pilihan strategi yang dijalankan. Strategi yang menitik beratkan pengembangan pasar keuangan (pasar modal) yang jauh melampaui pasar barang dan pasar tenaga kerja mengindikasikan keberpihakan strategi tersebut kepada pemilik modal dan bukan masyarakat pada umumnya.

Dalam pasar modal, maka kelompok tertentu saja yang memiliki akses cukup dan mampu memanfaatkan pasar modal untuk memperoleh keuntungan ekonomi, sementara sebagian besar masyakarat tidak dapat melakukannya. Jika perkembangan pasar modal yang selalu diikuti dengan perkembangan industri besar memiliki daya saing yang memadai, untuk pasar domestik maupun pasar global, maka strategi tersebut berpihak pada usaha besar yang dimiliki oleh sebagian kecil rakyat Indonesia, dan sebagian besar dari industri besar tersebut dimiliki oleh investor asing.

Rakyat Indonesia yang menurut bangun ekonomi sebagaimana tersebut dalam UUD 1945 adalah berada pada tatanan usaha koperasi dan usaha kecil. Sayangnya, kelompok ini tidak mempunyai kemampuan cukup untuk melakukan akses pada pasar modal dan bahkan sering membutuhkan bantuan pemerintah hanya untuk memanfaatkan fasilitas perbankan. 
Pengembangan pasar modal dan usaha besar memang dapat memacu pertumbuhan ekonomi yang lebih pesat, jika dibandingkan strategi yang berpihak pada ekonomi tradisional (UKM) dan koperasi. Namun strategi yang berorientasi pada pertumbuhan saja akan memicu adanya kesenjangan ekonomi yang tajam. Trade off antara strategi pertumbuhan dan pemerataan perlu dicarikan jalan keluar secara bijaksana. Sejarah telah membuktikan bahwa strategi pembangunan yang tidak berpihak pada rakyat dan konstitusi, pada akhirnya akan mengalami kegagalan. Hasil strategi tersebut pasti tidak dapat dinikmati oleh sebagian besar rakyat Indonesia dan hanya akan menghasilkan pengangguran, kemiskinan dan kesenjangan.

Oleh sebab itu, strategi pembangunan untuk meningkatkan daya saing harus dipilih dengan mengacu pada pembangunan berkesinambungan dan pembangunan manusia seutuhnya bagi kesejahteraan masyarakat Indonesia, yaitu (1) pertumbuhan berbasis modal yang mengandalkan trickle-down efect tidak dapat dilanjutkan dan perlu diganti dengan trickle-up effect, (2) menempatkan masyarakat sebagai sasaran pembangunan harus diakhiri dan diganti dengan menempatkan masyarakat sebagai pelaku pembangunan bersama-sama pemerintah.

\subsection{Strategi Meningkatkan Produktivitas}

Strategi meningkatkan produktivitas adalah strategi untuk meningkatkan kinerja usaha melalui peningkatan produktivitas SDM yang ada dalam usaha tersebut. Strategi untuk meningkatkan produktivitas dipahami sebagai suatu strategi yang mampu mengelola input dalam jumlah yang sama untuk menghasilkan output yang lebih besar. Di samping itu strategi peningkatan produktivitas harus dapat memberikan pilihan strategi yang dapat meningkatkan efisiensi sehingga dengan jumlah input yang lebih rendah, mampu menghasilkan output yang sama.

Strategi pengembangan produktivitas, hasilnya akan terlihat dari kemampuan negara dalam menghadapi persaingan dan kemampuan negara untuk beradaptasi dengan perubahan lingkungan, baik lingkungan internal maupun eksternal. Strategi pengembangan produktivitas negara dapat ditempuh dengan melakukan strategi untuk (1) mengembangkan jumlah dan kualitas wirausaha Indonesia sehingga mendekati porsi yang ideal dibandingkan jumlah penduduk Indonesia, (2) perbaikan sistem manajemen dan birokrasi, (3) melakukan inovasi teknologi dan engineering, (4) meningkatkan kualitas sumber daya manusia, serta (5) mengembangkan budaya produktif di semua lini usaha.

\subsection{Strategi pengembangan wirausaha dapat dilakukan dengan cara :}

1. Program pengembangan wirausaha dilakukan pemerintah melalui program-program pengembangan jiwa wirausaha di kalangan kampus. 
Strategi ini dilakukan dengan memberikan pembekalan konsep dasar wirausaha, baik yang diprakarsai oleh pemerintah maupun CSR perbankan nasional. Selain itu diberikan pembekalan kepada dosen yang mengajar mata kuliah kewirausahaan yang terdapat di dalam kurikulum operasional program studi, serta membiayai pelaksanaan praktek wirausaha di kampus-kampus.

2. Mendorong munculnya pengusaha pemula dengan memberikan kemudahan fasilitas usaha, kemitraan, dan kerjasama. Strategi memberikan akses pembiayaan melalui KUR, kemudahan akses pasar dan kemudahan berusaha juga dilakukan.

3. Memberikan kemudahan bagi UKM untuk masuk pada pasar ekspor dengan memberikan insentif ekspor dan keringanan pajak atas hasil ekspor.

4. Mengembangkan investasi dengan melakukan perluasan fasilitas investasi, fasilitas kepabeanan dan pengembangan kawasan industri, serta melakukan penataan dalam sistem logistik nasional dan penataan hubungan industri.

\subsection{Strategi Perbaikan Sistem Manajemen dan Birokrasi dapat dilakukan dengan cara :}

1. Melakukan deregulasi dan debirokratisasi untuk memudahkan pelayanan publik dan menekan biaya pengurusan izin usaha, sehingga dapat memperkecil high cost economic yang membebani pelaku usaha.

2. Meningkatkan akuntabilitas pelayanan publik dengan memenuhi ketersediaan teknologi informasi dan komunikasi di seluruh jajaran birokrasi, mulai dari birokrasi yang paling rendah di tingkat kelurahan hingga birokrasi tertinggi di tingkat walikota dan gubernur, juga dalam lingkup kementerian.

\subsection{Strategi Melakukan Inovasi Teknologi dan Engineering dapat dilakukan dengan cara :}

1. Meningkatkan kemampuan perguruan tinggi untuk melakukan riset, serta mendorong pelaku usaha untuk mengalokasikan sebagian dana CSR guna melengkapi dana riset yang diberikan pemerintah secara terbatas.

2. Meningkatkan motivasi bagi para peneliti dengan memberikan sertifikasi hak kekayaan intelektual dan penghargaan lainnya bagi para peneliti yang menghasilkan temuan teknologi ramah lingkungan dan dapat digunakan untuk melestarikan lingkungan hidup dan menjamin pembangunan berkelanjutan.

3. Memberikan kemudahan fasilitas usaha yang dibutuhkan oleh para pelaku usaha yang dalam menjalankan usahanya dengan memperhatikan faktor ekternalitas, melalui kegiatan perusahaan yang melestarikan 
lingkungan hidup di sekitar usahanya (misalnya membangun tempat pembuangan limbah pabrik), dan sebaliknya memberikan sanksi tegas bagi pelaku usaha yang melanggar.

\subsection{Strategi Peningkatan Kualitas Sumber Daya Manusia dapat dilakukan dengan cara :}

1. Mendirikan pusat penterjemahan nasional sehingga semua ilmu pengetahuan dari berbagai bangsa dapat diserap oleh para pekerja, baik yang diserap melalui bacaan langsung maupun melalui pendidikan dan pelatihan yang telah dari para pendidik yang telah dibekali lengkap dengan berbagai ilmu pengetahun yang dibutuhkan.

2. Mengembangkan standar kompetensi dengan memberikan sertifikasi ketenagakerjaan setelah melalui program pendidikan dan pelatihan yang berbasis kompetensi, baik yang dilakukan oleh Diklat perusahaan maupun oleh pemerintah melalui Diklat pada kementerian atau instansi terkait.

3. Memberikan penghargaan yang memadai bagi tenaga kerja maupun tenaga profesi, seperti dokter dan tenaga pendidik, serta memberikan kesempatan yang seluas-luasnya untuk meningkatkan kompetensi dan keahliannya dengan dukungan fasilitas dan dana dari negara dengan mengikuti syarat dan prosedur yang ditentukan.

4. Meningkatkan kualitas hidup pekerja dengan perbaikan gizi, kesehatan dan kesejahteraan pekerja sebagai bagian dari strategi pembangunan manusia seutuhnya.

5. Menciptakan iklim investasi UMKM untuk memberdayakan sektor informal guna mereposisi pengiriman tenaga kerja Indonesia karena sektor informal merupakan katup pengaman terjadinya pengangguran; Reposisi ini diperlukan untuk meningkatkan martabat bangsa dan pekerja itu sendiri di mata dunia dengan tidak mengirimkan tenaga kerja Indonesia ke luar negeri, kecuali untuk teknisi.

\subsection{Strategi Pengembangan Budaya Produktif dapat dilakukan dengan cara:}

1. Memberikan suasana kerja yang menjamin berlangsungnya budaya produktif, antara lain memberikan lingkungan kerja yang nyaman dan fasilitas kerja yang memadai dengan memberikan jaminan kelangsungan pasokan listik yang memadai dan berkesinambungan.

2. Mendorong pelaku usaha untuk menerapkan budaya organisasi yang menuntut para pekerja untuk produktif, dengan menerapkan sistem punishment dan reward yang jelas bagi para pekerja menggunakan merit system dalam menentukan jenjang karir bagi setiap pekerja. 
3. Mendorong pelaku usaha untuk menerapkan sistem penggajian yang berbasis pada model remunerasi yang menentukan gaji berdasarkan produktivitas pekerja; ini harus dilakukan dengan memberikan contoh bahwa di instansi pemerintah yang menerapkan sistem remunerasi dapat mendorong produktivitas pejabat publik dalam melayani masyarakat.

4. Melalui manajemen pelaku usaha atau petugas penyuluh pada instansi terkait, dilakukan bimbingan bagi pekerja agar termotivasi untuk meningkatkan produktivitas kerjanya dengan meyakinkan dan mencontohkan bahwa pekerja yang produktif adalah pekerja yang bermartabat dan dibutuhkan oleh lingkungan usahanya, serta diperhitungkan dalam pergaulan dengan sesama pekerja.

\section{SIMPULAN}

Kebijakan Ekonomi dan Peningkatan Daya Saing Indonesia Menghadapi Masyarakat Ekonomi ASEAN 2015 diperlukan, (1) Strategi Peningkatan Daya Saing, (2) Strategi Pembangunan Yang Berpihak Pada Rakyat dan Konstitusi, (3) Strategi Meningkatkan Produktivitas, (4) Strategi Pengembangan Wirausaha, (5) Strategi Perbaikan Sistem Manajemen dan Birokrasi, (6) Strategi Melakukan Inovasi Teknologi dan Engineering, (7) Strategi Peningkatan Kualitas Sumber Daya Manusia dan (8) Strategi Pengembangan Budaya Produktif. 


\section{DAFTAR PUSTAKA}

Ansoff. H.I and E.D Mc. Donnell.1990. Implating Strategic Management. Prentice-Hall International (UK) Ltd.

Bustami. 2015. Menuju Asean Economic Community.

David. Jr. 2015. Strategic Management Concept and Cases. Pearson. Fifteenth Edition.

Grant. Robert M., 1995. Contemporery Strategy Analysis. International Edition.

Hrebiniak. L.G. 2005. Making Strategy Leading Effective Execution and Change. Wharton School Publishing. New Yersey.

Kuntadi. 2005. Peranan Pengusaha Daerah Dalam Menghadapi Masyarakat Ekonomi ASEAN-2015.

Nazara. S. 2015. Perkembangan Perekonomian Indonesia. Makalah Disampaikan Pada Kwik Gian Gie School of Business. Jakarta. Oktober. 2015.

Simanjuntak P. 2015. Strategi Peningkatan Produktivitas dan Daya Saing Indonesia. Seminar Segmen Integrasi ECOSOC. Jakarta, 24-25 Februari 2015.

Stiglitz.2003. Globalisasi dan Kegagalan Lembaga-Lembaga Keuangan Internasional. Terjemahan Ahmad Lukman. Penerbit PT Ina Publikatama. Jakarta.

Undang-Undang Dasar Republik Indonesia 1945.

Undang-Undang Republik Indonesia Nomor 5 Tahun 1999 tentang Larangan Praktek Monopoli dan Persaingan Usaha Tidak Sehat. Pasal 2-3.

Wangke Humphmey. 2015. Peluang Indonesia Dalam Masyarakat Ekonomi ASEAN- 2015. 
